\title{
Identification of Pathogenic Leptospira in Rat and Shrew Populations Using rpoB Gene and Its Spatial Distribution in Boyolali District
}

\author{
Identifikasi Leptospira Patogen pada Populasi Tikus dan Celurut \\ Menggunakan Gen rpoB dan Distribusi Spasialnya di Kabupaten Boyolali
}

\author{
Dyah Widiastuti*, Zumrotus Sholichah*, Agustiningsih**, Nastiti Wijayanti****
}

\begin{abstract}
*Banjarnegara Research and Development of Zoonosis Control Unit, Banjarnegara, Indonesia, **Biomedical and Basic Health Technology of Research and Development Center, Jakarta, Indonesia ***Faculty of Biology, Gadjah Mada University, Yogyakarta, Indonesia
\end{abstract}

\begin{abstract}
Leptospirosis becomes health problem in Indonesia. Until April 2014, leptospirosis cases transmitted by rats were reported in Boyolali with case fatality rate (CFR) by $83.3 \%$. Leptospira genus consists of various serovars and genetic types living in different environment. Leptospira species classification based on rpoB gene could be used as this gene has high polymorphism level. This study aimed to identify Leptospira serovars in rat population using kinship analysis based on rpoB gene polymorphism, and describe spatial distribution of rats with Leptospira positive in Boyolali District. A cross-sectional study was conducted on April 2014 at Sindon Village in Ngemplak Subdistrict and Jeron Village in Nogosari Subdistrict, Boyolali District. Polymerase Chain Reaction test was performed on 104 rat kidney samples from two locations of study. Spatial analysis was conducted to map distribution of rats with Leptospira positive. There were six positive rpoB gene samples in Rattus tanezumi, Rattus argentiventer and Suncus murinus. Five of six positive samples showed the closest genetic kinship to Leptospira borgpetersenii serovar Sejroe based on rpoB gene. One isolate did not have a close genetic kinship to any serovar included in the cluster. Spatial analysis based on home range buffer zone showed rats with Leptospira positive were found in 30 meter and 150 meter from leptospirosis patients. Keywords: Leptospira, rpoB, spatial

Abstrak

Leptospirosis merupakan masalah kesehatan di Indonesia. Hingga April 2014, dilaporkan kasus leptospirosis yang ditularkan oleh tikus di Kabupaten Boyolali dengan angka kematian 83,3\%. Genus Leptospira terdiri dari ratusan serovar dan tipe genetik yang hidup di pelbagai jenis habitat. Pengelompokan spesies Leptospira berdasarkan gen rроB dapat digunakan karena tingkat polimorfisme gen tinggi. Penelitian ini bertujuan untuk mengidentifikasi serovar bakteri Leptospira pada populasi tikus di Kabupaten Boyolali menggunakan analisis hubungan kekerabatan didasarkan pada polimorfisme gen rpoB dan menggambarkan distribusi spasial tikus positif Leptospira di Kabupaten Boyolali. Penelitian potong lintang dilaksanakan pada April 2014 di Desa Sindon Kecamatan Ngemplak dan Desa Jeron Kecamatan Nogosari, Kabupaten Boyolali. Pemeriksaan Polymerase Chain Reaction dilakukan pada 104 sampel ginjal tikus dari dua lokasi penelitian. Analisis spasial sederhana dilakukan untuk memetakan sebaran tikus yang positif Leptospira. Terdapat enam sampel positif gen rpoB Leptospira pada Rattus tanezumi, Rattus argentiventer dan Suncus murinus. Lima dari keenam sampel menunjukkan hubungan kekerabatan yang paling dekat dengan Leptospira borgpetersenii serovar Sejroe berdasarkan gen rpoB. Satu isolat tidak memiliki hubungan kekerabatan yang dekat dengan serovar manapun yang masuk dalam cluster. Analisis spasial berdasarkan jarak aktivitas harian tikus menunjukkan tikus positif Leptospira ditemukan berada dalam kisaran 30 meter dan 150 meter dari penderita leptospirosis.

Kata kunci: Leptospira, rpoB, spasial

How to Cite: Widiastuti D, Sholichah Z, Agustiningsih, Wijayanti N. Identification of pathogenic Leptospira in rat and shrew populations using rpoB gene and its spatial distribution in Boyolali District. Kesmas: National Public Health Journal. 2016; 11 (1): 32-38. (doi:10.21109/kesmas.v11i1. 798)

Correspondence: Dyah Widiastuti, Banjarnegara Research and Development of Zoonosis Control Unit, Selemanik street No. 16A, Banjarnegara, Indonesia, Phone: +62 286-594972, e-mail: umi.azki@gmail.com

Received: March $8^{\text {th }} 2016$

Revised: May $12^{\text {th }} 2016$

Accepted: August $11^{\text {th }} 2016$
\end{abstract}

Copyright @ 2016, Kesmas: National Public Health Journal, p-ISSN: 1907-7505, e-ISSN: 2460-0601, Accreditation Number: 56/DIKTI/Kep/2012, http://journal.fkm.ui.ac.id/kesmas 


\section{Introduction}

Leptospirosis in the recent decades appeared as outbreak or extraordinary incidence in several countries in Asia, South and Central America, and the United States. This condition has made the disease is included in new or emerging infectious diseases. ${ }^{1}$ This disease as caused by the bacterium Leptospira is still a public health problem in some areas in Indonesia.

Leptospirosis outbreak in Indonesia occurred in Jakarta in 2002, Sleman in 2008 and 2009, and the districts of Bantul in 2010. Cases of leptospirosis in Boyolali have been reported since 2012 involving two cases, and in 2013 increased to four cases. ${ }^{2}$ From April 3 to March 2014, six cases of leptospirosis were reported and five of them died. In 2012 and 2013, no cases of leptospirosis deaths in Boyolali was found, but in 2014 there were deaths due to leptospirosis reached $83.3 \% .^{3}$ It is necessary to increase the management of leptospirosis cases, especially for early detection, so that appropriate measures and prompt treatment can be performed to reduce leptospirosis fatality and death.

Leptospirosis is spread through direct contact or indirectly by pathogenic Leptospira bacteria. Rats are a common source of infection throughout the world. ${ }^{4}$ Countries in Asia Pacific report that rats are detected carry Leptospira in their body. ${ }^{5}$ Rats are animals that have adapted to human life and living close to humans. Leptospira excreted in the urine of rat in the long term and can survive in the environment that would allow them to act as transmitting Leptospira to humans and the environment. ${ }^{6}$ Thus, checking up Leptospira in rats is necessary. In addition, shrew is also known to transmit the Leptospira bacteria into the environment through its urine. ${ }^{6}$

The genus Leptospira is a group of organisms that have tremendous diversity, consisting of hundreds of serovar and genetic types that live in various types of environments or habitats. In this genus, there are pathogenic serovar that highly select the host, and harmless serovar that live freely in the aquatic water environment. At first, this genus is only divided into two species, namely: pathogenic (L. interrogans) and saprophytic ( $L$. biflexa). The second type is a normal biota that is often found in the surface water. ${ }^{7}$

Leptospira is now grouped into 17 groups genomospecies based on genetic similarity with various molecular methods. ${ }^{8}$ Based on this categorization, pathogenic Leptospira species is divided into eight, namely L. interrogans sensu stricto, $L$. weilii, $L$. borgpetersenii, $L$. noguchii, L. santarosai, L. alexanderi, L. kirschnneri (formerly known as L. alstoni) and L. genospecies. ${ }^{1}$ The division of this species was based on phylogenetic analysis of rrs gene (ribosomal RNA gene) that encodes the $16 \mathrm{~S}$ rRNA gene. However, the ability to distinguish one species and another species for gene rrs is relatively weak, due to the absence of a high degree of polymorphism in the gene, even at the level of complete gene grouping. ${ }^{5}$ Leptospira classification by genetic variation will add information to conduct epidemiological analysis.

Since the presence of multiple species in an environment is associated with a particular reservoir, RpoB gene is known to be useful for classifying species of bacteria, including group Spirocaeta. Leptospira is a genus belonging to groups Spirocaeta. 6 The use of rpoB gene to differentiate Leptospira species has also been developed by La Scola. ${ }^{7}$

The use of Geographic Information System (GIS) is presented in spatial to display and compare the distribution object layout relationship, to describe position or location of disease spread and other health condition. ${ }^{9}$ GIS method is very good for epidemiologic visualization and GIS analysis can be used to describe the disease pattern and the source of infection that is important in controlling and terminating the transmission chain correctly. ${ }^{10,11}$ This study aimed to identify serovar Leptospira that exist in the rat population in Boyolali by analyzing the kinship based on gene polymorphism rpoB and describing the spatial distribution of rats with Leptospira positive in Boyolali.

\section{Method}

The survey locations were chosen based on the latest cases of leptospirosis found, that were distributed in Ngemplak Subdistrict and Nogosari Subdistricts. Rat trapping was conducted at the Sindon Village in Ngemplak Subdistrict and Jeron Village in Nogosari Subdistrict, Boyolali District in April 2014. A total of 385 single live trap purposively were installed in residential areas around the home of patients with leptospirosis in both villages. During January-March 2014, leptospirosis cases were found two adjascent subdistricts of Boyolali District, namely Ngemplak Subdistrict and Nogosari Subdistrict. Leptospirosis case data was secondary data obtained from the local health office.

The single live traps were layed for two days inside and outside the house. The caught mice and shrew were identified by the Center for Research and Development (Balai Litbang P2B2) in Banjarnegara by using identification key. ${ }^{12}$ Then, mice and shrew's kidney organ were taken and further inserted into a tissue lysis buffer that had been placed in a $1.5 \mathrm{ml}$ microcentrifuge tubes. Kidney samples were stored at a temperature of $4^{\circ} \mathrm{C}$ until the examination process done. DNA isolation process was done by using a Tissue Genomic DNA Mini Kit reagent (Geneaid). The examination stages were conducted in the working manner recommended by the kit.

The Polymerase Chain Reaction (PCR) process performed on DNA samples obtained using the following 
primer: rpoB-F-CCTCATGGGTTCCAACATGCA and rpoB-R-CGCATCCTCRAAGTTGTAWCCTT using Go Taq Green Master Mix (Promega). ${ }^{7}$ The PCR stages are as follows: predenaturation $94^{\circ} \mathrm{C}$ for 2 minutes, followed with 40 cycles of amplification consisting of denaturation at $94^{\circ} \mathrm{C}$ for 30 seconds, annealing at $55^{\circ} \mathrm{C}$ for 1 minute, extension at $72^{\circ} \mathrm{C}$ for $1 \mathrm{~min}$ followed by a final extension for $20 \mathrm{~min}$ at $72^{\circ} \mathrm{C}$. Analysis of the PCR result was performed by electrophoresis using a $1.5 \%$ agarose at 100 volts for 15 minutes. Specific DNA visualization was performed using UV transiluminator. Sample was tested positive when the electrophoresis results showed that the DNA bands was in the position of $600 \mathrm{bp}$.

The PCR rpoB gene products were purified using the Gel/PCR DNA Fragments Extraction Kit (Geneaid) according to the protocol recommended by the kit, sequencing reaction using a primer used in the PCR process. PCR product subsequently were sent to the sequencing service provider (first base) in Jakarta to determine the nucleotide sequences.

The phylogenetic tree is based on the partial rpoB gene DNA sequences with the reference sequences based on the neighbor-joining using MEGA6. ${ }^{13}$ Bootstrapping program to measure the level of confidence conducted using 1000 data sets. The data point location coordinates of patients with leptospirosis and rats with Leptospira positive were analyzed spatially using ArcView 3.3 software to map the spread of leptospirosis patients and Leptospira positive. Mapping the location of the rats Leptospira positive were analyzed based daily rats cruis- ing buffer (home range). Rats home range buffer were grouped at a distance of 30 meter, 60 meter, 90 meter, 120 meter and 150 meter. ${ }^{14,15}$

\section{Results}

Rat trapping results in Jeron Village and Sindon Village showed their pretty solid population. It is based on the success trap numbers that were high in both villages by percentage $16.49 \%$ for Jeron Village and $10.75 \%$ for Sindon Village. The composition of rats and shrew species found in both villages was shown in Figure 1.

Figure 1 showed that there were two species of rats found in Sindon Village, namely Rattus tanezumi ( $R$. tanezumi) and Rattus norvegicus ( $R$. norvegicus)and one species of insectivore that was Suncus murinus. Three species of rats that were $R$. tanezumi, $R$. norvegicus and $R$. argentiventer and one species of insectivore that Suncus murinus were found in Jeron Village. Rat species in these two villages was dominated by $R$. tanezumi. A total of 91 samples of rat kidneys consisting of 39 from Sindon Village and 52 from Jeron Village were tested by PCR to detect Leptospira DNA. Six of them showed positive results for the rpoB gene (Figure 2).

Six kidney samples that gave positive results of the rpoB gene were obtained from three tanezumi rats $(R$. Tanezumi), two ricefield rats ( $R$. Argentiventer) and one shrew (S. murinus). This showed that the rodents and insectivores carried Leptospira in their bodies. More results were presented in Table 1.

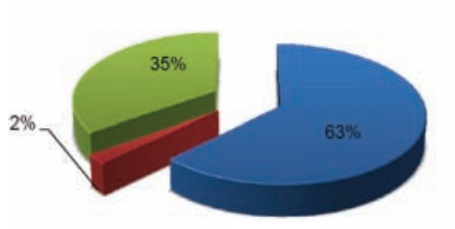

(a)

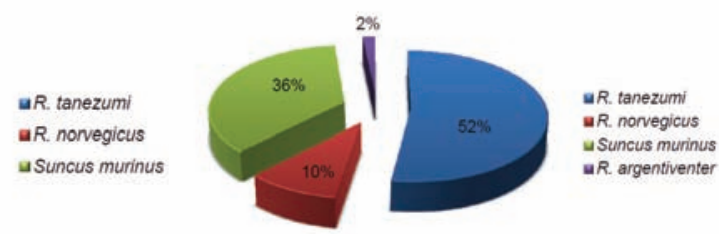

(b)

Figure 1. Rat and Shrew Species Caught in Sindon Village (a) and Jeron Village (b), Boyolali District

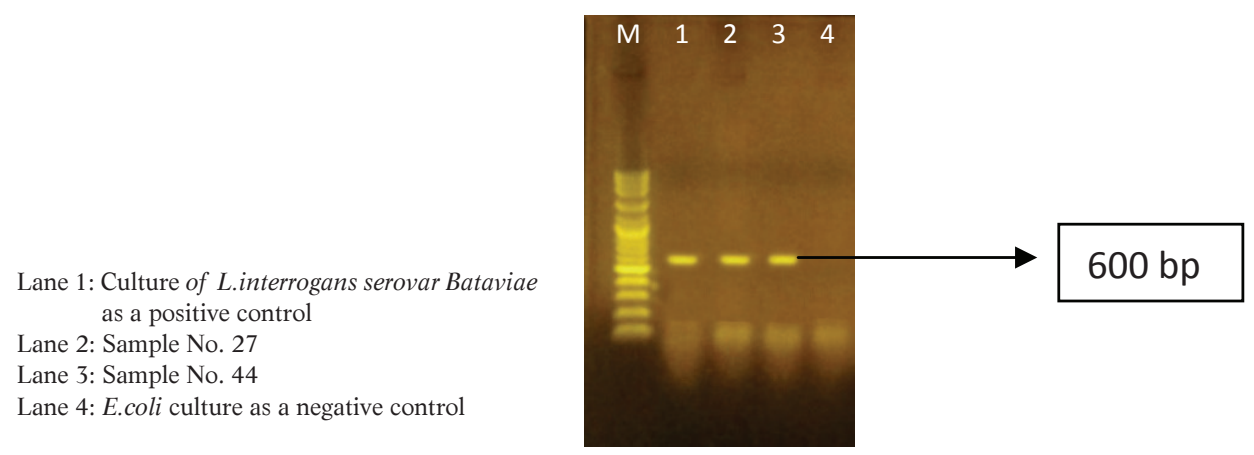

Figure 2. Amplification Product of the PCR Process with rpoB Gene 
Widiastuti et al, Identification of Pathogenic Leptospira in Rat Shrew Populations Using rpoB Gene and Its Spatial Distribution

Table 1. Details of Rat Trapping Results and Leptospira Detection Based on the Detection of Leptospira rpoB Gene

\begin{tabular}{llccc}
\hline Origin & Spesies & Number of Samples & $\begin{array}{c}\text { Number of Positive } \\
\text { Samples }\end{array}$ & $\begin{array}{c}\text { Positive Mice } \\
(\%)\end{array}$ \\
\hline Jeron village & R. tanezumi & 31 & 2 & 3.8 \\
& R. norvegicus & 6 & 0 & 0 \\
& R. argentiventer & 1 & 1 & 1.9 \\
Sindon village & S. murinus & 14 & 2 & 3.8 \\
& R. tanezumi & 11 & 1 & 2.6 \\
& R. norveigicus & 1 & 0 & 0 \\
& S. murinus & 5 & 0 & 0 \\
\hline
\end{tabular}

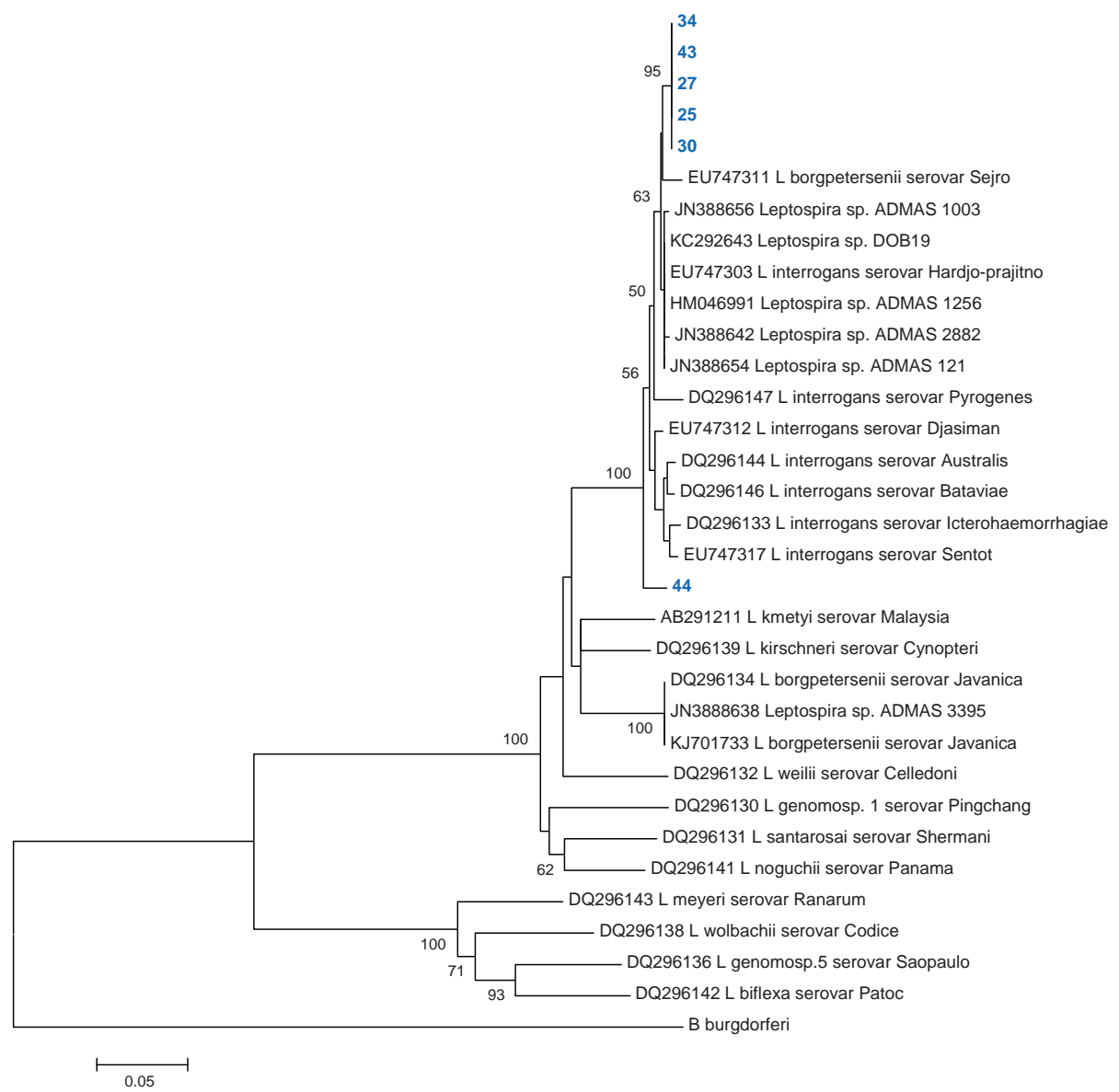

Figure 3. Leptospira Phylogenetic Tree - Phylogenetic Analysis Conducted by Neigbor-Joining Method Using MEGA6 to 1000 Repetitions (Bootsraping), Boyolali Origin Leptospira was Marked with Blue

Phylogenetic tree based on partial nucleotide rpoB gene sequence showed a breakdown constructed by bootstrap test using neighboor-joining method in the MEGA6 program (Figure 3). Phylogenetic analysis showed that 5 strains of Leptospira found in the rat population in Boyolali clustered with Leptospira borgpetersenii serovar Sejroe. One sample showed was not clustered with the sequence reference.

Buffer analysis results indicated that coordinates of leptospirosis cases and rats with Leptopsira positive in Sindon Village located in a distance of 150 meter. In
Jeron Village, there were coordinates point of mice with Leptospira positive, within a distance of less than 30, 90 dan 150 meters from the location of leptospirosis cases. Location of rats with Leptospira positive in Jeron Village and Sindon Village gathered in a residential area. There was only one detected rat with Leptospira positive in the rice field found in Jeron Village.

\section{Discussion}

Rats trapping showed trap success index by $10.75 \%$ in Sindon Village, and by $16.49 \%$ in Jeron Village. Rat 


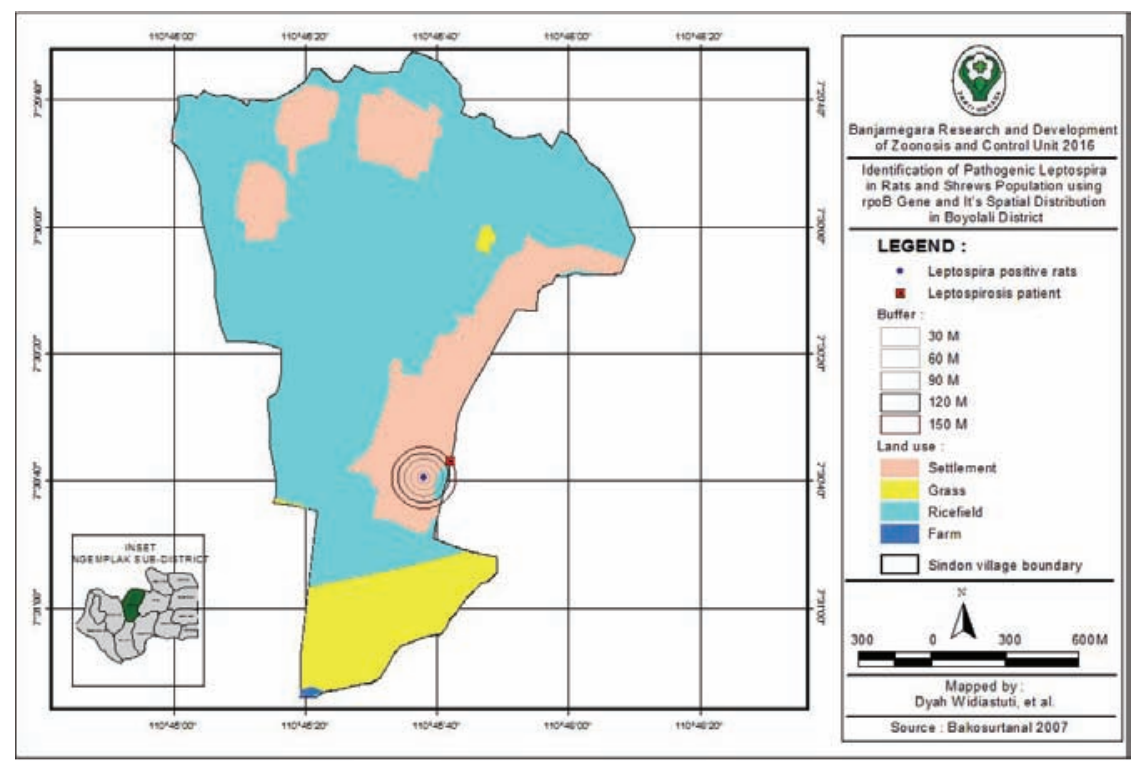

(a)

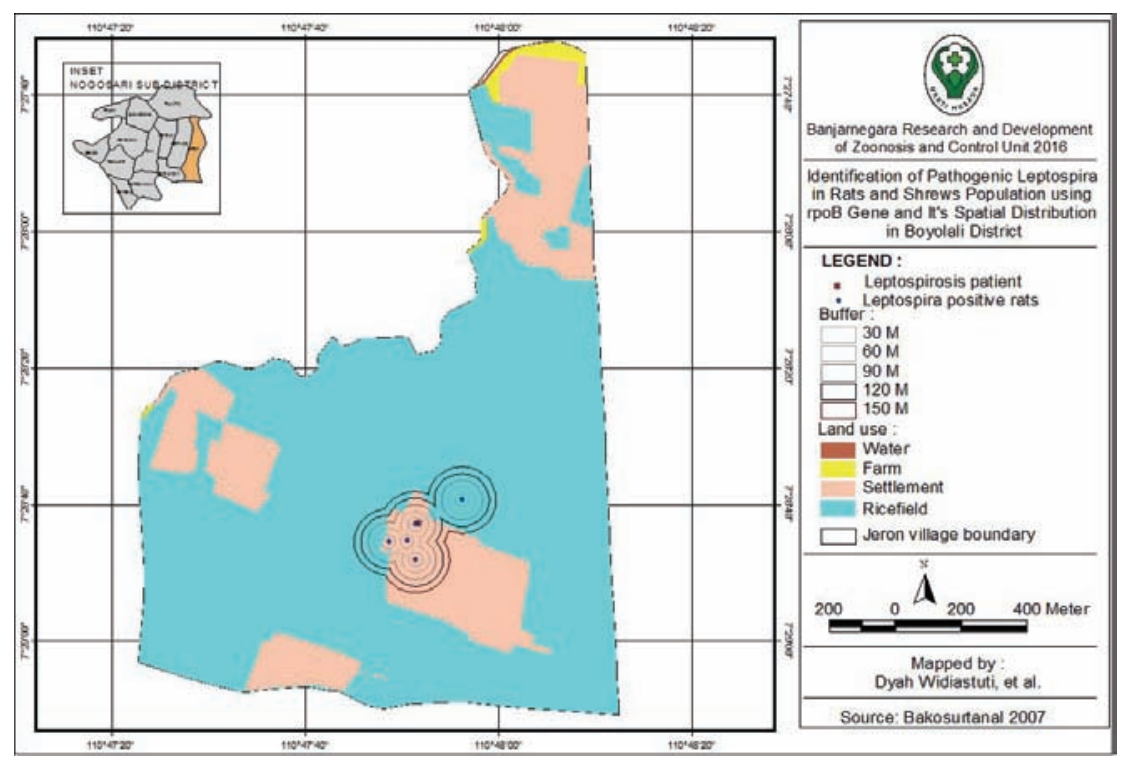

(b)

Figure 4. Buffer Home Range Mapping of Rats with Leptospira Positive with Leptospirosis Patients in Sindon Village (a) and Jeron Village (b)

species in both villages was dominated by Rattus tanezu$m i$, reaching $63 \%$ in Sindon Village and $52 \%$ in Jeron Village.

Detecting rpoB gene based on PCR showed that of six Leptospira positive rats and shrew, three of them were $R$. tanezumi species. This indicated that $R$. tanezumi is the most abundant species giving positive results containing pathogenic Leptospira. Leptospira infection in rats can be influenced by spesies. ${ }^{16,17}$ Previous studies showed the most abundant species found infected by Leptospira were $R$. tanezumi and $R$. norvegicus. ${ }^{18-22}$ This showed that $R$. tanezumi could serve as a source of Leptospira infection and spread to humans and the environment. Possibility of human exposed to Leptospira from $R$. tanezumi is even higher because of close living habitat of rats to human life. Applin et $a l,{ }^{23}$ explained that was commonly found in urban and rural areas.

L. borgpetersenii serovar Sejroe infection was report- 
ed detected in seven clinical blood serum specimens derived from humans in New Caledonia. ${ }^{24}$ Sakamoto, ${ }^{25}$ reported that a Japanese tourist was serovar infected after a vacation in Bali. Desvars et al, ${ }^{26}$ stated that serovar Sejroe was a major serovar causing abortion in cattle in the Reunion Island. Chronic infection of Leptospira in cattle can cause reproductive problems, such as abortion and low fertility. ${ }^{27}$ In the study area, there were quite a lot of farm animals, such as goats, sheep and cows. Based on data from the Central Statistics Agency, there were 562 cows, 278 goats and 95 head of sheeps at Jeron Village in 2014. Meanwhile, cattles in Sindon village consisted of 159 cows, 175 goats and 194 sheeps. ${ }^{28-29}$ Cattles can be a source of infection for humans and the environment.

Isolate number 44 was shown mostly different from the other five isolates. Isolate number 44 also did not have close kinship with any serovar. This indicated that probably the isolate number 44 is a pathogenic Leptospira serovar derived from different ancestors with five other isolates. The point of location where the positive Leptospira rats found were mapped to determine areas with possible transmission. Spatial analysis was done by using the buffer analysis of rats daily cruising. Spatial distribution indicated that the position of positive Leptospira rats either in Sindon or in Jeron were around the latest leptospirosis cases in both villages.

In Jeron village, there is a positive shrew found in a distance of less than 30 meter from leptospirosis cases. Meanwhile, in Sindon Village, positive rat was found at a distance of 150 meter from leptospirosis case. The location of leptospirosis cases in these two villages were within the range of daily activity area of positive rats, enabling acquiring leptospirosis from Leptospira-infected rats. Priyambodo, ${ }^{14}$ mentioned that the average distance of rats daily activity at a time when food abundant was 30 meter, and not more than 200 meter. Villafane et al, ${ }^{15}$ reported that the average longest distance taken by Rattus norveigicus was 33.7 meter.

Rat trapping in this study were performed three and four weeks after the death cases of leptospirosis. Although it cannot be concluded that the source of infection leptospirosis cases who died were from the positive rats found in this study, the discovery of the positive rats remains a concern because it can serve as a source of transmission. Leptospira in environmental viability depends on $\mathrm{pH}$, temperature and the presence of pollutants. Leptospira is sensitive to acids and can live in fresh water for approximately one month. In the sea water, sewage and undiluted urine, the bacteria will quickly die. Leptospira can live for three weeks in the flooded land. ${ }^{30}$ It also suggests that Leptospira was still in the neighborhood and can be a source of infection given the Leptospira to be excreted into urine of mice for a long time, and Leptospira is able to live in a suitable environment for months.

The PCR method can be performed at various locations bacteria genome Leptospira, so making this method becomes a reliable method. Delay in leptospirosis diagnosis can cause severity that likely to result in death. Conventional methods, such as culture or Microscopic Agglutination Test (MAT), require live cultures of bacteria Leptospira with high bio-hazard level. Another advantage of the PCR method is its ability to detect Leptospira bacteria from samples. Joshi et al,31 explained that the PCR method has high accuracy, because of DNA amplification is done specifically, so that the samples containing only small amounts of DNA can still be detected. Besides, the PCR requires a relatively short time.

Rapid diagnosis of leptospirosis is very important in the handling this disease. Delay in diagnosis can lead to various complications, such as inflammation of the pancreas, brain hemorrhage, pulmonary hemorrhage, and others that require intensive therapy.

\section{Conclusion}

From rats and shrew samples examined, six samples were rpoB gene positive from $R$. tanezumi, $R$. argentiventer and $S$. murinus species. Five of the six positive samples showed the closest kinship to L. borgpetersenii serovar Sejroe. One isolate does not have a close kinship to any serovar included in the cluster. Rats with Leptospira positive are found within the home range (30 meter and 150 meter). Location of rats with positive Leptospira was accumulated around the leptospirosis patients.

\section{Recommendation}

People in location of study should increase awareness towards transmission of leptospirosis disease because in their environment, rats with pathogenic Leptospira positive are already found. For further studies, detection of Leptospira in environment (water and land) or other reservior in Boyolali District can be performed.

\section{References}

1. Hui Yi L, Sing Hwa N, Chia Ying T, Abdullah A, Azmi F, Samsuki N, et al. Leptospirosis [Internet]. Infectious Diseases [online]. 2011; 2(12): WMC002772. Available from: http://www.webmedcentral.com/article_view/2772

2. Dinas Kesehatan Kabupaten Boyolali. Laporan Kasus Leptospirosis Tahun 2012-2014 Kabupaten Boyolali. Boyolali: Dinas Kesehatan Kabupaten Boyolali; 2014.

3. Pramestuti N. Laporan Survei P2B2 Daerah Potensi KLB. Banjarnegara: Balai Litbang P2B2 Banjarnegara.2014

4. Green-McKenzi J WHS. Leptospirosis [Internet]. 2015 [cited 2015 Aug 31]. Available from: http://emedicine.medscape.com/article/788751overview 
5. Victoriano AFB, Smythe LD, Gloriani-barzaga N, Cavinta LL, Kasai T, Limpakarnjanarat K, et al. Leptospirosis in the Asia Pacific region. BMC Infectious Diseases. 2009; 9: 147 - 55.

6. Scholl AM, Hammerl JA, Schmidt S, Ulrich RG, Pfeffer M, Wall D, et al. Leptospira spp. in Rodents and Shrews in Germany. International Journal of Environmental Research and Public Health. 2014; 11 (8): 7562-74.

7. Scola BL, Bui LTM, Baranton G, Khamis A, Raoult D. Partial rpoB gene sequencing for identification of Leptospira species. FEMS Microbiology Letters. 2006; 263:142-7.

8. Smythe L, Adler B, Hartskeerl RA, Galloway RL, Turenne CY, Levett $\mathrm{PN}$ and the International Committee on Systematics of Prokaryotes Subcommittee on the taxonomy of Leptospiraceae. Classification of Leptospira genomospecies 1, 3, 4 and 5 as Leptospira alstonii sp. nov., Leptospira vanthielii sp. nov., Leptospira terpstrae sp. nov. and Leptospira yanagawae sp. nov., respectively. International Journal of Systematic and Evolutionary Microbiology. 2013; 63: 1859-62

9. Febrian F, Solikhah. Analisis spasial kejadian penyakit leptospirosis di kabupaten sleman propinsi Daerah Istimewa Yogyakarta tahun 2011. Jurnal Kesehatan Masyarakat. 2013; 7 (1): 7-14.

10. Royal Tropical Institute. Geographic information systems (GIS) [Internet]. Royal Tropical Institute. 2014 [cited 2014 Jun 20]. Available from: http://www.kit.nl/smartsite.shtml?ch=FAB\&id=3918

11. Johnson CP, Johnson J. GIS: A Tool for monitoring and management of epidemics [online]. In: Map India 2001 Conference. New Delhi: 2001 [cited 2016 Jan 4]. Available from: www.cdac.in/index.aspx?id=pdf_geom6

12. Tamura K, Stecher G, Peterson D, Filipski A, Kumar S. MEGA6 : Molecular evolutionary genetics analysis Version 6.0. Molecular Biology and Evolution. 2013; 30 (12): 2725 - 29.

13. Suyanto A. Rodent di Jawa. Jakarta: Pelita Indonesia; 2006.

14. Priyambodo S. Pengendalian hama tikus terpadu. Jakarta: PT Penebar Swadaya; 2009.

15. Villafañe IEG, Muschetto E, Busch M. Movements of norway rats (Rattus norvegicus) in two poultry farms, exaltación de la cruz. Mastozoologia Neotropical. 2008; 15 (2): 203 - 8.

16. AMK MR. Preventive measures for leptospirosis: rodent control [Internet]. Indian Journal of Medical Microbiology. 2006; 24(4): 325328.

17. Ikawati B, Widiastuti D. Dominant factors infl uencing Leptospira sp infection in rat and suncus. Health Science Indonesia. 2012; 3(2): 27-30.

18. Farida D, Wahyuni S, Ristiyanto. Spot survey reservoir leptospirosis di Desa Bakung, Kecamatan Jogonalan, Kabupaten Klaten, Jawa Tengah.
Buletin Penelitian Kesehatan. 2006; 34: 105 - 10.

19. Yunianto B, Ramadhani T, Marbawati D, Sholichah Z. Studi epidemiologi leptospirosis di Kota Semarang (Tahap II) [Laporan Penelitian]. Banjarnegara: Balai Litbang P2B2 Banjarnegara; 2009.

20. Faria MT de, Calderwood MS, Athanazio DA, McBride AJ, Hartskeerl RA, Pereira MM, et al. Carriage of Leptospira interrogansamong domestic rats from an urban setting highly endemic for leptospirosis in Brazil. Acta Tropica. 2008; 108 (1): 1 - 5.

21. Agudelo-flórez P, Londoño AF, Quiroz VH, Ángel JC, Moreno N, Loaiza ET, et al. Prevalence of Leptospira spp. in urban rodents from a groceries trade center of Medellín, Colombia. Tropical Medicine. 2009; 8 (5): 906-10.

22. Munoz-Zanzi C, Mason M, Encina C, Gonzalez M, Berg S. Household characteristics associated with rodent presence and leptospira infection in rural and urban communities from Southern Chile. Tropical Medicine. 2014; 90 (3): 497 - 506.

23. Aplin KP, Brown PR, Jacob J, Krebs C, Singleton GR. Field methods for rodent studies in Asia and the Indo-Pacific. Canberra: ACIAR Monograph No.100; 2003

24. Perez J, Goarant C. Rapid Leptospira identification by direct sequencing of the diagnostic PCR products in New Caledonia. BMC Microbiology. 2010; 10: 325-35.

25. Sakamoto M, Kato T, Sato F, Yoshikawa K, Yoshida M, Shiba K, et al. A case of leptospirosis caused by Leptospira borgpetersenii serovar sejroe infected in Bali Island, Indonesia. Kansenshogaku Zasshi. 2005; 79 (4): $294-8$.

26. Desvars A, Michault A, Bourhy P. Leptospirosis in the western Indian Ocean islands: what is known so far? Veterinary Research. 2013; 88 (40): 1 - 11

27. World Health Organization. Leptospirosis [Online]. WHO Regional Office for South-East Asia [cited 2015 Jul 31]. Available from: http://www.searo.who.int/about/administration_structure/cds/CDS_le ptospirosis-Fact_Sheet.pdf

28. Badan Pusat Statistik. Kecamatan Nogosari dalam angka tahun 2015. Boyolali: Badan Pusat Statistik; 2015.

29. Badan Pusat Statistik. Kecamatan Ngemplak dalam angka tahun 2015. Boyolali: Badan Pusat Statistik; 2015.

30. Levett PN. Leptospirosis. Clinical Microbiology Reviews. 2001; 14 (2): $296-326$.

31. Joshi M, Deshpande JD. Polymerase chain reaction: methods, principles and application. International Journal of Biomedical Research. 2010; 2 (1): 81 - 97. 